\title{
Low dissolved oxygen levels increase stress in piava (Megaleporinus obtusidens): iono-regulatory, metabolic and oxidative responses
}

\author{
CARLOS E. COPATTI ${ }^{1}$, KEIDI C.S. BOLNER ${ }^{2}$, ÉRIKA P. LONDERO ${ }^{2}$, FELIPE L. DE \\ ROSSO$^{2}$, MARIA A. PAVANATO ${ }^{2}$ and BERNARDO BALDISSEROTTO ${ }^{2}$
}

\author{
${ }^{1}$ Instituto de Biologia, Universidade Federal da Bahia, Av. Adhemar de Barros, 500, 40170-110 Ondina, Salvador, BA, Brazil \\ ${ }^{2}$ Departamento de Fisiologia e Farmacologia, Universidade Federal de Santa Maria, \\ Av. Roraima, 1000, Camobi, 97105-900 Santa Maria, RS, Brazil \\ Manuscript received on April 23, 2018; accepted for publication on October 11, 2018
}

\begin{abstract}
How to cite: COPATTI CE, BOLNER KCS, LONDERO EP, ROSSO FL, PAVANATO MA AND BALDISSEROTO B. 2019. Low dissolved oxygen levels increase stress in piava (Megaleporinus obtusidens): iono-regulatory, metabolic and oxidative responses. An Acad Bras Cienc 91: e20180395. DOI. 10.1590/0001-3765201920180395.
\end{abstract}

\begin{abstract}
The aquatic environment presents daily and/or seasonal variations in dissolved oxygen (DO) levels. Piava faces different DO levels in the water due to its distributional characteristics. The goal of this study was to describe the effects of low DO levels on plasma ion, biochemical and oxidative variables in piava juveniles. Fish were exposed to different DO levels, including 1.0, 2.0, 3.0, 4.0 and $5.0 \mathrm{mg} \mathrm{L}^{-1}$ of DO for $96 \mathrm{~h}$, after which blood and tissue samples (liver, kidney, gill and muscle) were collected. The decrease in DO levels decreased plasma $\mathrm{Na}^{+}, \mathrm{Cl}^{-}, \mathrm{K}^{+}$and $\mathrm{NH}_{3}$ levels as well as protein and glycogen levels in the liver, kidney and muscle; increased $\mathrm{Na}^{+} / \mathrm{K}^{+}$-ATPase activity in the gills and kidney as well as glucose and ammonia levels in the liver, kidney and muscle; and increased lactate levels in the kidney and muscle. Thiobarbituric acid-reacting substances, catalase and non-protein thiol levels decreased in the tissues of piavas exposed to low DO levels. It is concluded that piava can apparently cope with hypoxic conditions; however, low DO levels are a stressor, and the tolerance of piava to hypoxia involves iono-regulatory, metabolic and oxidative adjustments.
\end{abstract}

Key words: iono-regulatory, glucose, lactate, $\mathrm{Na}^{+}, \mathrm{K}+$-ATPase activity, oxidative stress.

\section{INTRODUCTION}

The aquatic environment presents natural daily and/ or seasonal variations in dissolved oxygen (DO) levels (Riffel et al. 2012). To supplement oxygen demand during periods of low DO levels in the water (hypoxia), many fishes have evolved the ability to survive such periods, although there is large interspecific variation in the severity and duration of hypoxia that can be tolerated (Speers-Roesch et

Correspondence to: Carlos E. Copatti

E-mail: carloseduardocopatti@yahoo.com.br

ORCid: https://orcid.org/0000-0002-0114-0334 al. 2013). Fish exposed to hypoxia respond with different metabolic strategies to increase their ability to extract oxygen from the medium (Lushchak et al. 2001, Wilhelm Filho et al. 2005, Lushchak and Bagnyukova 2006, Welker et al. 2013), however, the effects of hypoxia on fish metabolism and physiology are still not fully understood, especially in freshwater neotropical fish.

Aquatic hypoxia triggers in fish for example decreased metabolic rate (e.g., reduction in locomotion activity, feeding, growth and reproduction) (Dalla Via et al. 1994) and increased 
ventilation rate, hemoglobin $\mathrm{O}_{2}$ affinity (Perry and McDonald 1993, Wu 2002) and anaerobic metabolism (Claireaux and Chabot 2016). The latter should cause glycolytic activation with glycogen or glucose as the substrates and lactate as an intermediate product (Dalla Via et al. 1994). For example, Wilhelm Filho et al. (2005) and Riffel et al. (2012) verified that piapara and piavuçu (respectively Megaleporinus elongatus and Megaleporinus macrocephalus, previously known as Leporinus elongates and Leporinus macrocephalus) under acute hypoxia reduced their metabolic rates, but only M. macrocephalus reduced antioxidant levels.

Hypoxia also triggers chemoreceptors in the gills (Milsom et al. 1999) and catecholamine release (Reid and Perry 2003), promoting reflex changes in the branchial vasculature, elevating blood pressure in the branchial perfusion and an increase in lamellar flux, which induces an increase in the effective respiratory surface area (Sundin 1999). This circulatory change probably distorts and widens gill tight junctions, and, consequently, they become more permeable to ions (Gonzalez and McDonald 1994, Riffel et al. 2012), affecting the ion balance in fish, where $\mathrm{Na}^{+} \mathrm{K}^{+}$-ATPase in chloride cells is the major driving force for ion transport in the fish branchial system (Huang et al. 2010). Therefore, higher $\mathrm{Na}^{+} / \mathrm{K}^{+}$-ATPase activity would also contribute to reduce ion loss (Moyson et al. 2015).

It was expected that the reduction in oxygen availability would result in a concomitant decrease in reactive oxygen species (ROS) production because oxygen is required for the generation of ROS (Wilhelm Filho et al. 2005, Welker et al. 2013, Pelster et al. 2018). More specifically, hypoxia-tolerant fish appear to have an anticipatory response during low-oxygen availability by enhancing their ability to quench ROS production upon return to normal oxygen concentrations (Lushchak and Bagnyukova 2006). Once produced, ROS at high concentrations can damage cells and tissues, particularly targeting proteins, lipids and nucleic acids, often leading to cumulative organ injury. To prevent tissue damage in situations of variable oxygen availability when there is the danger of inordinate accumulation of ROS, animals have developed a defense system for rapidly breaking down ROS (Wilhelm Filho 1996). The liver has a high potential for ROS generation, which seems to be efficiently counterbalanced by powerful protective mechanisms to detoxify and repair damaged lipids and proteins (Lushchak and Bagnyukova 2006). Several different antioxidant enzymes, such as catalase, and superoxidase dismutase, are involved, and the nonenzymatic elements glutathione and metallothioneins also plays a critical role in removing free radicals from cells (Lushchak and Bagnyukova 2006, Riffel et al. 2012).

Piava (Megaleporinus obtusidens Valenciennes (1847), previously known as Leporinus obtusidens) is an omnivorous fish species of high commercial importance in Brazil and is native to South America (Copatti and Amaral 2009). This species is distributed throughout São Francisco, Uruguai and Paraná River Basins and faces different DO levels in the water due to its distributional characteristics. For example, near the headwater of the river current velocity and water flow are slower and, consequently, present lower DO levels (Pio et al. 2018). In addition, decrease in DO levels are triggered by high temperatures, organic matter decomposition, aquatic organisms' respiration (Esteves 1998) and anthropogenic pollution. In addition, in fish farms, it is also susceptible to hypoxia conditions due to high stocking density conditions (Copatti et al. 2008). However, we are not aware of any study that has investigated the tolerance of piavas to the acute exposure to hypoxia and the effects on their plasma ion, metabolic and oxidative variables. Therefore, in the present study, biochemical variables, ion plasma levels, $\mathrm{Na}^{+} / \mathrm{K}^{+}$-ATPase activity and oxidative stress were examined to provide an integrated view of tolerance 
and energy homeostasis in piava juveniles under hypoxia conditions.

\section{MATERIALS AND METHODS}

\section{ANIMALS}

Piava juveniles $(11.47 \pm 0.58 \mathrm{~cm}, 26.01 \pm 1.11 \mathrm{~g})$ were purchased from local suppliers and brought to the Laboratório de Fisiologia de Peixes at the Universidade Federal de Santa Maria (UFSM). Before experimentation, fish from the holding tank $(250 \mathrm{~L})$ were acclimated to conditions including DO of $5.16( \pm 0.22) \mathrm{mg} \mathrm{L}^{-1} \mathrm{O}_{2}$, temperature of $22.9( \pm 0.17){ }^{\circ} \mathrm{C}, \mathrm{pH}$ of $7.46( \pm 0.04)$, alkalinity of $20( \pm 0.2) \mathrm{mg} \mathrm{CaCO}_{3} \mathrm{~L}^{-1}$, hardness of $30( \pm 0.1)$ mg $\mathrm{CaCO}_{3} \mathrm{~L}^{-1}$ and total $\mathrm{NH}_{3}$ levels less than 0.15 $\mathrm{mg} \mathrm{L}^{-1}$ for 2 weeks. The fish were fed once daily with commercial food (320 $\mathrm{g} \mathrm{kg}^{-1}$ crude protein; 3600 kcal digestible energy, Supra). Individuals fasted for a period of $24 \mathrm{~h}$ prior to the experiment. The experimental protocol was approved by the Committee on Animal Experimentation - UFSM (protocol n ${ }^{\circ}$ 24/2007).

\section{EXPERIMENTAL PROCEDURE}

After acclimation, piavas were transferred to continuously aerated $40-\mathrm{L}$ tanks (10 juveniles per tank), where they remained for $96 \mathrm{~h}$. DO levels were measured every $2 \mathrm{~h}$ using a YSI oxygen meter (model Y5512, Yellow Springs, USA). Different DO levels (in $\mathrm{mg} \mathrm{L}^{-1}$ ) were tested: $1.0 \pm 0.35,2.0$ $\pm 0.58,3.0 \pm 0.48,4.0 \pm 0.57$ and $5.0 \pm 1.21$ (in triplicate). Maintenance of the DO levels occurred by regulating air bubbling and/or bubbling nitrogen (for deoxygenation, medicinal nitrogen) in the water until reaching a constant level of DO. Tanks were covered with a plastic to reduce air diffusion, mainly in the lower DO levels. These DO levels were chosen because they are sub lethal values that affect $M$. macrocephalus oxidative stress (Riffel et al. 2012).
Tanks were siphoned daily to remove residue and faces and, as a result, at least $20-40 \%$ of the water was replaced with water with DO levels previously adjusted. Fish were not fed during the experiments.

PLASMA IONS

At the end of the experiment, fish ( $\mathrm{n}=4$ per tank; 12 per treatment) were anaesthetized with $50 \mu \mathrm{L}$ $\mathrm{L}^{-1}$ of eugenol, and blood samples $(1 \mathrm{~mL})$ were collected using heparinized syringes, transferred to $2-\mathrm{mL}$ plastic tubes and centrifuged at $3000 \mathrm{~g} \mathrm{(5}$ $\min$ at $5{ }^{\circ} \mathrm{C}$ ) to separate the plasma. The samples were stored under constant refrigeration $\left(-20{ }^{\circ} \mathrm{C}\right)$. The $\mathrm{Na}^{+}$and $\mathrm{K}^{+}$plasma levels were determined with a B262 flame spectrophotometer (Micronal, São Paulo, Brazil) and $\mathrm{Cl}^{-}$according to methods of Zall et al. (1956). $\mathrm{NH}_{3}$ levels were determined following methods of Verdouw et al. (1978).

\section{BIOCHEMICAL DETERMINATIONS}

After blood collection, fish ( $\mathrm{n}=4$ per tank; 12 per treatment) were euthanized by their spinal cord, and the liver, kidney, muscle and gills were collected and stored in liquid nitrogen until further analysis. Tissue extracts were made by homogenization with $100 \mathrm{mg} \mathrm{L}^{-1}$ of $20 \%$ trichloride acetic acid using a Potter-Elvehjem homogeniser (3 $\mathrm{min}$ in ice bath) and centrifugation at $3000 \mathrm{~g}\left(5 \mathrm{~min}\right.$ at $\left.5{ }^{\circ} \mathrm{C}\right)$. The supernatant was used to determine the levels of glucose and glycogen (DuBois et al. 1956), protein (Lowry et al. 1951), lactate (Harrower and Brown 1972) and ammonia (Verdouw et al. 1978) in the liver, kidney and muscle.

For analysis of $\mathrm{Na}^{+} / \mathrm{K}^{+}$-ATPase enzyme activity in the gills and kidney, samples were homogenized in a Potter-Elvehjem homogeniser with a sucroseEDTA-TRIS homogenizing buffer at a $\mathrm{pH}$ of 7.5 and a 1:5 ratio. Afterward, the homogenate was centrifuged for $5 \mathrm{~min}$ at $5000 \mathrm{~g}$, and the supernatant was used for analysis (modified from Flik et al. 1983). 


\section{OXIDATIVE STRESS ANALYSIS}

A portion of the liver was homogenized as described by Riffel et al. (2012) and used for measurement of biomarker of oxidative lipid peroxidation levels using a thiobarbituric acid-reacting substances (TBARS) assay (Buege and Aust 1978) at 535 nm. Catalase (CAT) activity was measured by the decrease in hydrogen peroxide $\left(\mathrm{H}_{2} \mathrm{O}_{2}\right)$ by the absorption at $240 \mathrm{~nm}$ (Boveris and Chance 1973). The total superoxide dismutase (SOD) activity was based on the inhibition rate of adenochrome autocatalytic generation at $480 \mathrm{~nm}$ (Fridovich 1974). The content of non-protein thiols (NPSH) is an indirect measure of reduced glutathione (GSH) and was measured after reaction with 5,5'-dithiobis (2-nitrobenzoic acid) at $412 \mathrm{~nm}$. Proteins were eliminated by the addition of $0.5 \mathrm{M}$ perchloric acid (Ellman 1959).

\section{STATISTICAL ANALYSIS}

The data are reported as mean $\pm \mathrm{SEM}$, with fish as the statistical units ( $\mathrm{n}$ total $=150$ ). Homogeneity of variance among the groups was verified using the Levene test. The relationship between DO levels in the water and the corresponding variables results was expressed by regression analyses (SigmaPlot 8.0 software). If no significant relationship was found, the differences between treatment means were analyzed by one-way analysis of variance (ANOVA) followed by Tukey's post hoc test. Differences were considered significant at $\mathrm{P}<0.05$.

\section{RESULTS}

There was no mortality throughout the experiment. The piava proportionally decreased their protein and glycogen levels and increased their glucose and ammonia levels in the liver, kidney and muscle with decreasing levels of DO levels. The decrease in DO levels proportionally caused an increase in lactate levels in the kidney and muscle, but these levels remained stable in the liver (Table I).

Plasma ions $\left(\mathrm{Na}^{+}, \mathrm{Cl}^{-}, \mathrm{K}^{+}\right.$and $\left.\mathrm{NH}_{3}\right)$ levels of piava juveniles proportionally decreased as DO levels decreased (Table II). Gill and kidney $\mathrm{Na}^{+} /$ $\mathrm{K}^{+}$-ATPase activity proportionally increased with decreasing DO levels (Table III).

Piava juveniles exposed to 2.0 and $3.0 \mathrm{mg} \mathrm{L}^{-1}$ of DO levels presented significantly lower TBARS and NPSH levels compared to fish maintained at $5.0 \mathrm{mg} \mathrm{L}^{-1}$ of DO levels. In addition, fish subjected to $1.0 \mathrm{mg} \mathrm{L}^{-1}$ of DO levels presented significantly lower TBARS than those maintained at $5.0 \mathrm{mgL}^{-1}$ of DO levels. The CAT had significantly lower activity in fish exposed to $1.0 \mathrm{mg} \mathrm{L}^{-1}$ of DO levels than at $5.0 \mathrm{mg} \mathrm{L}^{-1}$ of DO levels $(\mathrm{P}<0.05)$. SOD was not affected significantly by exposure to the different DO levels (Table IV).

\section{DISCUSSION}

In the present study, piava juveniles probably used the anaerobic route in response to hypoxia, because glycogen and protein levels in the tissues decreased with the reduction of DO levels, increasing glucose in the tissues to provide energy. The response to hypoxia is the regulation of the energy supply by regulating the glycolysis of storage glycogen, which is a readily available energy resource (Bickler and Buck 2007). In addition, the increase of lactate levels in the kidney and muscle also indicates the use of an anaerobic route to furnish energy to cope with hypoxia, because lactate can be converted to glucose via gluconeogenesis (Teixeira et al. 2017). The oxygen in tissues becomes insufficient for metabolism and the fish use anaerobic glycolysis for cellular energy supplies, resulting in plasma lactate accumulation (Iversen et al. 2003). ATP supply from anaerobic metabolism may therefore make a substantial contribution to total metabolism during hypoxia in these juveniles. Similarly, the capacity of aerobic metabolic pathways of ATP supply were reduced during hypoxia in a congeneric 
TABLE I

Effects of different dissolved oxygen (DO) levels $\left(\mathrm{mg} \mathrm{L}^{-1}\right)$ on biochemical variables in tissues of piava juveniles.

\begin{tabular}{|c|c|c|c|c|c|}
\hline DO & Protein & Glycogen & Glucose & Lactate & Ammonia \\
\hline \multicolumn{6}{|c|}{ Liver } \\
\hline 1.0 & $54.31 \pm 2.31$ & $72.80 \pm 3.84$ & $75.80 \pm 3.51$ & $90.31 \pm 2.51$ & $103.89 \pm 8.7$ \\
\hline 2.0 & $53.80 \pm 2.13$ & $74.61 \pm 3.54$ & $77.90 \pm 4.79$ & $94.87 \pm 3.04$ & $95.64 \pm 6.32$ \\
\hline 3.0 & $68.40 \pm 2.51$ & $92.35 \pm 4.22$ & $59.82 \pm 2.66$ & $83.40 \pm 2.54$ & $89.31 \pm 6.21$ \\
\hline 4.0 & $83.13 \pm 3.62$ & $103.44 \pm 13.65$ & $40.84 \pm 2.84$ & $87.30 \pm 2.13$ & $86.36 \pm 4.21$ \\
\hline 5.0 & $87.41 \pm 3.84$ & $106.40 \pm 12.41$ & $42.39 \pm 2.54$ & $85.19 \pm 1.86$ & $71.42 \pm 4.13$ \\
\hline Eq. & $\begin{array}{c}\mathrm{y}=40.75+9.55 \mathrm{x} \\
\mathrm{r}^{2}=0.93 ; \mathrm{P}=0.009\end{array}$ & $\begin{array}{c}y=61.11+9.60 x \\
r^{2}=0.93 ; P=0.007\end{array}$ & $\begin{array}{c}\mathrm{y}=9.51-10.39 \mathrm{x} \\
\mathrm{r}^{2}=0.87 ; \mathrm{P}=0.022\end{array}$ & No regression & 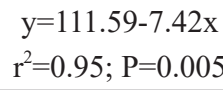 \\
\hline \multicolumn{6}{|c|}{ Kidney } \\
\hline 1.0 & $22.41 \pm 1.21$ & $34.15 \pm 2.12$ & $39.60 \pm 3.15$ & $108.34 \pm 11.54$ & $56.94 \pm 3.51$ \\
\hline 2.0 & $24.63 \pm 1.56$ & $33.87 \pm 2.47$ & $29.81 \pm 2.51$ & $95.44 \pm 8.62$ & $53.13 \pm 3.21$ \\
\hline 3.0 & $39.35 \pm 2.01$ & $55.13 \pm 2.87$ & $21.74 \pm 1.65$ & $83.62 \pm 6.51$ & $46.19 \pm 2.45$ \\
\hline 4.0 & $45.39 \pm 2.05$ & $69.43 \pm 3.14$ & $15.90 \pm 1.54$ & $60.38 \pm 5.41$ & $42.24 \pm 2.65$ \\
\hline 5.0 & $46.44 \pm 1.98$ & $68.34 \pm 3.24$ & $12.40 \pm 1.05$ & $63.90 \pm 2.53$ & $23.33 \pm 1.47$ \\
\hline Eq. & $\begin{array}{c}\mathrm{y}=15.00+6.88 \mathrm{x} \\
\mathrm{r}^{2}=0.91 ; \mathrm{P}=0.012\end{array}$ & $\begin{array}{l}y=21.00+10.39 x \\
r^{2}=0.88 ; P=0.018\end{array}$ & $\begin{array}{c}\mathrm{y}=44.38-6.83 \mathrm{x} \\
\mathrm{r}^{2}=0.97 ; \mathrm{P}=0.003\end{array}$ & $\begin{array}{l}y=119.52-12.39 x \\
r^{2}=0.92 ; P=0.010\end{array}$ & $\begin{array}{c}y=67.78-7.81 x \\
r^{2}=0.89 ; P=0.016\end{array}$ \\
\hline \multicolumn{6}{|c|}{ Muscle } \\
\hline 1.0 & $19.40 \pm 1.21$ & $54.15 \pm 3.45$ & $88.97 \pm 3.52$ & $3113.15 \pm 286.31$ & $107.47 \pm 9.51$ \\
\hline 2.0 & $33.15 \pm 1.85$ & $74.13 \pm 4.98$ & $85.53 \pm 3.21$ & $2553.69 \pm 245.87$ & $105.53 \pm 8.56$ \\
\hline 3.0 & $43.31 \pm 1.54$ & $87.42 \pm 6.54$ & $69.74 \pm 2.58$ & $2234.61 \pm 142.31$ & $100.15 \pm 8.21$ \\
\hline 4.0 & $57.51 \pm 2.14$ & $115.13 \pm 10.25$ & $60.71 \pm 2.41$ & $1443 . .69 \pm 218.73$ & $91.19 \pm 6.31$ \\
\hline 5.0 & $59.6 \pm 2.06$ & $126.84 \pm 14.52$ & $59.60 \pm 2.87$ & $1396.13 \pm 113.58$ & $79.21 \pm 5.24$ \\
\hline Eq. & $\begin{array}{l}y=11.17+10.48 x \\
r^{2}=0.96 ; P=0.003\end{array}$ & $\begin{array}{l}y=35.62+18.64 x \\
r^{2}=0.98 ; P<0.001\end{array}$ & $\begin{array}{c}\mathrm{y}=96.98-8.16 \mathrm{x} \\
\mathrm{r}^{2}=0.94 ; \mathrm{P}=0.006\end{array}$ & $\begin{array}{c}y=3511.47-454.40 x \\
r^{2}=0.95 ; P=0.004\end{array}$ & $\begin{aligned} y & =117.97-7.09 x \\
r^{2} & =0.93 ; P=0.009\end{aligned}$ \\
\hline
\end{tabular}

Protein is expressed as mg $\mathrm{g}$ tissue ${ }^{-1}$, Glycogen is expressed as mmol glycosyl-glucose $\mathrm{g}$ tissue ${ }^{-1}$, Glucose, lactate and ammonia are

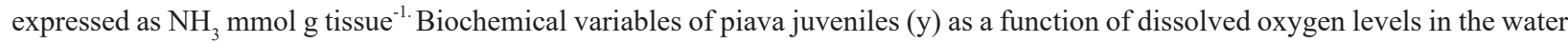
(x). Data are expressed as the mean $\pm \operatorname{SEM}(n=12$ per treatment).

species of oscar (Astronotus crassipinnis), while that of anaerobic pathways increased (Chippari-Gomes et al. 2005).

The largest amount of ammonia is produced in the liver of fish and is then carried by the circulatory system to the gills for excretion. Ammonia is also produced by the gills, kidney and muscle (Bolner et al. 2014). In this regard, our results showed that under hypoxia ammonia levels increased in the liver, kidney and muscle of piava juveniles, but plasma ammonia decreased. Consequently, piava exposed to hypoxia may be increasing ammonia excretion.
Some freshwater fish under hypoxia increase their gill permeability due to intensification of their gill ventilation rate and increase the water volume and oxygenation for gas exchange in the gills ( $\mathrm{Xu}$ et al. 2006, Robertson et al. 2015), both of which contribute to ion loss (McDonald et al. 1991), higher blood flux (Sundin 1999) and ion efflux (Rosso et al. 2006), with the resultant decrease of plasma $\mathrm{Na}^{+}$ and $\mathrm{Cl}^{-}$levels (Pierson et al. 2004). Low DO levels provoked a reduction of plasma ion levels in piava, which could reduce the costs of gill ion pumping.

The $\mathrm{Na}^{+} / \mathrm{K}^{+}$-ATPase plays a very important role in the kidney and gills of teleosts (Evans 2011). 
TABLE II

Effects of different dissolved oxygen (DO) levels $\left(\mathrm{mg} \mathrm{L}^{-1}\right)$ on ion plasma levels $\left(\mathrm{mmol} \mathrm{L}^{-1}\right)$ in tissues of piava juveniles.

\begin{tabular}{|c|c|c|c|c|}
\hline DO & $\mathbf{N a}^{+}$ & $\mathrm{Cl}^{-}$ & $\mathbf{K}^{+}$ & $\mathbf{N H}_{3}$ \\
\hline 1.0 & $91.18 \pm 5.05$ & $88.22 \pm 7.50$ & $2.25 \pm 0.54$ & $3.90 \pm 0.71$ \\
\hline 2.0 & $92.02 \pm 7.85$ & $91.41 \pm 8.03$ & $4.29 \pm 0.38$ & $5.10 \pm 0.89$ \\
\hline 3.0 & $122.19 \pm 8.31$ & $138.93 \pm 10.21$ & $5.36 \pm 0.37$ & $5.30 \pm 0.74$ \\
\hline 4.0 & $176.49 \pm 10.54$ & $183.25 \pm 7.87$ & $6.41 \pm 0.59$ & $6.90 \pm 0.41$ \\
\hline 5.0 & $204.72 \pm 11.14$ & $225.68 \pm 7.35$ & $7.34 \pm 0.32$ & $7.20 \pm 0.54$ \\
\hline Eq. & $\begin{array}{l}y=43.85+31.15 x \\
r^{2}=0.93 ; P=0.009\end{array}$ & $\begin{array}{l}y=35.47+36.68 x \\
r^{2}=0.95 ; P=0.004\end{array}$ & $\begin{array}{c}\mathrm{y}=1.44+1.23 \mathrm{x} \\
\mathrm{r}^{2}=0.97 ; \mathrm{P}=0.002\end{array}$ & $\begin{array}{c}\mathrm{y}=3.16+0.84 \mathrm{x} \\
\mathrm{r}^{2}=0.95 ; \mathrm{P}=0.005\end{array}$ \\
\hline
\end{tabular}

Ion concentration in plasma of piava juveniles (y) as a function of dissolved oxygen levels in the water (x). Data are expressed as the mean $\pm \operatorname{SEM}(\mathrm{n}=12$ per treatment).

TABLE III

Effects of different dissolved oxygen (DO) levels $\left(\mathrm{mg} \mathrm{L}^{-1}\right)$ on $\mathrm{Na}^{+} / \mathrm{K}^{+}$-ATPase activity (nMPi.hr-1 mg protein $\left.^{-1}\right)$ in tissues of piava juveniles.

\begin{tabular}{ccc}
\hline DO & Gill & Kidney \\
\hline 1.0 & $43.64 \pm 3.51$ & $89.61 \pm 3.50$ \\
2.0 & $39.41 \pm 2.41$ & $53.84 \pm 5.21$ \\
3.0 & $25.47 \pm 2.58$ & $41.70 \pm 5.01$ \\
4.0 & $17.31 \pm 3.12$ & $43.50 \pm 2.86$ \\
5.0 & $14.40 \pm 2.81$ & $33.40 \pm 2.04$ \\
Eq. & $\mathrm{y}=51.82+7.86 \mathrm{x}$ & $\mathrm{y}=89.24+12.28 \mathrm{x}$ \\
$\mathrm{r}^{2}=0.94 ; \mathrm{P}=0.006$ & $\mathrm{r}^{2}=0.78 ; \mathrm{P}=0.048$ \\
\hline
\end{tabular}

$\mathrm{Na}^{+} / \mathrm{K}^{+}$-ATPase activity of piava juveniles (y) as a function of dissolved oxygen levels in the water (x). Data are expressed as the mean $\pm \operatorname{SEM}(\mathrm{n}=12$ per treatment $)$.

\section{TABLE IV}

Effects of different dissolved oxygen (DO) levels $\left(\mathrm{mg} \mathrm{L}^{-1}\right)$ on levels of thiobarbituric acid-reacting substances (TBARS), superoxide dismutase (SOD) and catalase (CAT) activities and non-protein thiol (NPSH) levels in the liver of piava juveniles.

\begin{tabular}{|c|c|c|c|c|}
\hline DO & TBARS & SOD & CAT & NPSH \\
\hline 1.0 & $4.16 \pm 0.69^{b}$ & $3.26 \pm 0.55^{\mathrm{a}}$ & $1.51 \pm 0.49^{\mathrm{b}}$ & $3.61 \pm 0.81^{\mathrm{ab}}$ \\
\hline 2.0 & $4.35 \pm 0.58^{\mathrm{b}}$ & $4.05 \pm 0.92^{\mathrm{a}}$ & $2.20 \pm 0.20^{\mathrm{ab}}$ & $1.73 \pm 0.63^{\mathrm{b}}$ \\
\hline 3.0 & $3.43 \pm 0.50^{\mathrm{b}}$ & $4.55 \pm 0.62^{\mathrm{a}}$ & $2.22 \pm 0.90^{\mathrm{ab}}$ & $2.72 \pm 0.64^{b}$ \\
\hline 4.0 & $4.66 \pm 0.57^{\mathrm{ab}}$ & $3.81 \pm 0.58^{\mathrm{a}}$ & $2.38 \pm 0.67^{\mathrm{ab}}$ & $3.98 \pm 0.82^{\mathrm{ab}}$ \\
\hline 5.0 & $6.75 \pm 0.19^{\mathrm{a}}$ & $5.52 \pm 0.58^{\mathrm{a}}$ & $3.61 \pm 0.78^{\mathrm{a}}$ & $6.60 \pm 1.46^{\mathrm{a}}$ \\
\hline
\end{tabular}

TBARS is expressed as nmol mg protein ${ }^{-1}$, SOD is expressed as units mg protein ${ }^{-1}$, CAT is expressed as $\mathrm{mmol} \mathrm{mg} \mathrm{protein}^{-1} \mathrm{~min}^{-1}$, and NPSH is expressed as nmol mg protein ${ }^{-1}$. Different letters indicate significant differences between treatments $(\mathrm{P}<0.05)$. Data are expressed as the mean $\pm \operatorname{SEM}(n=12$ per treatment $)$. 
Hypoxic conditions change the $\mathrm{Na}^{+} / \mathrm{K}^{+}$-ATPase activity in erythrocytes of various fish (Nikinmaa 2002). In the kidney of teleosts, $\mathrm{Na}^{+} / \mathrm{K}^{+}$-ATPase activity provides energy for ion transport, because the solute and water absorption is usually via the retention of $\mathrm{Na}^{+}$, led by the $\mathrm{Na}^{+} / \mathrm{K}^{+}$-ATPase activity in the basolateral membrane (Evans 1993). This is consistent with the increase of $\mathrm{Na}^{+} / \mathrm{K}^{+}$-ATPase activity in the gills and kidney of piava juveniles verified in this study during hypoxia, because the higher ion loss would induce higher $\mathrm{Na}^{+} / \mathrm{K}^{+}$ATPase activity in an attempt to regulate ion levels.

When the amount of ROS formed exceeds the endogenous antioxidant capacity of the organism, there is oxidative damage to lipids, DNA and proteins, resulting in oxidative stress (Lushchak and Bagnyukova 2006). The lower lipid peroxidation (TBARS) and antioxidant defenses (CAT and NPSH) in the liver of the piava juveniles exposed to hypoxia observed in our study was expected. Under these conditions, organisms seem not to undergo oxidative stress because the main source of ROS, the electron transport chain, is blocked or is less intense (Lushchak and Bagnyukova 2006). Our results showed that low DO levels were able to decrease the lipid peroxidation in the liver of piava juveniles. Consequently, the redox state of the cell changes (Oliveira et al. 2005), reducing the production of ROS and thereby decreasing lipid damage. On the other hand, the response of the ROS defense system to changing oxygen availability appears to be quite variable and species specific, where anaerobic pathway may lead to the formation of reactive oxygen species (ROS) (Lushchak and Bagnyukova 2006). However, hypoxia-induced oxidative stress has been detected in previous studies in goldfish (Carassius auratus) (Lushchak et al. 2001), common carp (Cyprinus carpio) (Lushchak et al. 2005), piapara (Wilhelm Filho et al. 2005) and Indian catfish (Clarias batrachus) (Tripathi et al. 2013).
ROS generated in tissues and subcellular compartments are maintained within the physiological levels when the antioxidant defenses are in a normal physiological state (Wilhelm Filho 1996). In the present study, SOD activity was stable in piava exposed to hypoxia, which could be related to mechanisms of these animals to prevent further oxidative damage in the event of future reoxygenation (Lushchak et al. 2001). In our study, the lowest concentration of oxygen showed lower activity of CAT compared to the control. This may have occurred due to a blockage of the electron transport chain or its operation at low capacity. Thus, there would be less $\mathrm{H}_{2} \mathrm{O}_{2}$ to be broken down by CAT, reducing its activity (Riffel et al. 2012).

As for non-enzymatic antioxidants, the content of NPSH, an indirect measure of GSH, which plays a central role in second line of antioxidant defenses (Azambuja et al. 2011), was lower in fish subjected to concentrations of 2 and $3 \mathrm{mg} \mathrm{L}^{-1}$ of DO levels. Riffel et al. (2012) showed that piavuçu exposed to $0.71 \mathrm{mg} \mathrm{L}^{-1}$ of DO levels for $96 \mathrm{~h}$ also presented lower NPSH levels compared to levels in normoxia. It appears that GSH is an important part of the antioxidant system in fish, because fish demonstrate strict maintenance of the cellular redox state and GSH levels even under prolonged stressful conditions (Lushchak and Bagnyukova 2006). In general, the decrease in antioxidants was a response to hypoxia observed in our results, and increased oxidative activity occurred in piava juveniles exposed to higher DO concentrations. It appears that a reduction of the energy available to piava (glycogen levels) under hypoxia reduces the formation of ROS.

\section{CONCLUSIONS}

Piava juveniles can apparently cope with hypoxic conditions; however, low DO levels are stressful. The tolerance of piava juveniles to hypoxia is 
facilitated by anaerobic metabolism and ionoregulatory, metabolic and oxidative adjustments.

\section{ACKNOWLEDGMENTS}

The authors thank Conselho Nacional de Desenvolvimento Tecnológico (CNPq) for financial support and research fellowship to Bernardo Baldisserotto.

\section{AUTHOR CONTRIBUTIONS}

Keidi C.S. Bolner and Felipe L. De Rosso conducted the experiments. Bernardo Baldisseroto was responsible for the sample design and coordination of the experiments. Carlos E. Copatti performed the statistical analyzes. Tissue analyzes were performed by Keidi C.S. Bolner, Felipe L. De Rosso, Maria A. Pavanato and Érika P. Londero. All authors contributed to the writing of the manuscript. The final revision of the manuscript with the corrections requested by the reviewers was provided by Carlos E. Copatti and Bernardo Baldisserotto.

\section{REFERENCES}

AZAMBUJA CR, MATTIAZZI J, RIFFEL APK, FINAMOR IA, GARCIA LO, HELDWEIN CG, HEINZMANN BM, BALDISSEROTTO B, PAVANATO MA AND LLESUY SF. 2011. Effect of the essential oil of Lippia alba on oxidative stress parameters in silver catfish (Rhamdia quelen) subjected to transport. Aquaculture 319: 156-161.

BICKLER PE AND BUCK LT. 2007. Hypoxia tolerance in reptiles, amphibians, and fishes: life with variable oxygen availability. Annu Rev Physiol 69: 145-170.

BOLNER KCS, COPATTI CE, ROSSO FL, LORO VL AND BALDISSEROTTO B. 2014. Water $\mathrm{pH}$ and metabolic parameters in silver catfish (Rhamdia quelen). Biochem Syst Ecol 56: 202-208.

BOVERIS A AND CHANCE B. 1973. The mitochondrial generation of hydrogen peroxide. Biochem J 134: 707716.

BUEGE JA AND AUST SD. 1978. Microsomal lipid peroxidation. Method Enzymol 52: 302-310.

CHIPPARI-GOMES AR, GOMES LC, LOPES NP, VAL AL AND ALMEIDA-VAL VMF. 2005. Metabolic adjustments in two Amazonian cichlids exposed to hypoxia and anoxia. Comp Biochem Physiol B 141: 347-355.
CLAIREAUX G AND CHABOT D. 2016. Responses by fish to environmental hypoxia: integration through Fry's concept of aerobic metabolic scope. J Fish Biol 88: 232251.

COPATTI CE AND AMARAL R. 2009. Osmorregulação em juvenis de piava, Leporinus obtusidens (Characiformes: Anastomidae), durante trocas do $\mathrm{pH}$ da água. Biodivers Pamp 7: 1-6.

COPATTI CE, DOS SANTOS TA AND GARCIA SFS. 2008. Stocking density and feeding frequency of the juveniles of the piavas Leporinus obtusidens Valenciennes, 1836 (Characiformes: Anostomidae). R Bras Agroc 14: 107-111.

DALLA VIA J, VAN DEN THILLART G, CATTANI O AND DE ZWANN A. 1994. Influence of long term hypoxia exposure on the energy metabolism of Solea solea. II Intermediary metabolism in blood, liver and muscle. Mar Ecol Prog Ser 111: 17-27.

DUBOIS M, GILLES KA, HAMILTON JK, REBERS PAAND SMITH F. 1956. Colorimetric method for determination of sugars and related substances. Anal Chem 28: 350-358.

ELLMAN GL. 1959. Tissue sulphydryl groups. Arch Biochem Biophys 82: 70-77.

ESTEVES FA. 1998. Fundamentos de limnologia. $2^{\mathrm{a}}$ ed., Rio de Janeiro: Interciência, Rio de Janneiro, Brasil, 602 p.

EVANS DH. 1993. Osmotic and ionic regulation. In: Evans DH (Ed), The Physiology of Fish, Boca Raton: CRC Press, Boca Raton, USA, p. 315-341.

EVANS DH. 2011. Freshwater fish gill ion transport: August Krogh to morpholinos and microprobes. Acta Physiol 202: 349-359.

FLIK C, WENDELAAR BONGA SE AND FENWICK JC. 1983. $\mathrm{Ca}^{2+}$-dependent phosphatase and ATPase activities in eel gill plasma membranes. I. Identification of $\mathrm{Ca}^{2+}$ activated ATPase activities with non-specific phosphatase activities. Comp Biochem Physiol B 76: 745-754.

FRIDOVICH I. 1974. Superoxide and evolution. Horiz Biochem Biophys 1: 1-37.

GONZALEZ RJ AND MCDONALD DG. 1994. The relationship between oxygen uptake and ion loss in fish from diverse habitats. J Exp Biol 190: 95-108.

HARROWER JR AND BROWN CH. 1972. Blood lactic acid. A micromethod adapted to field collection of microliter sample. J Appl Physiol 32: 224-228.

HUANG CY, CHAN PL AND LIN HC. 2010. $\mathrm{Na}^{+} / \mathrm{K}^{+}$-ATPase and vacuolar type $\mathrm{H}^{+}$-ATPase in the gills of the aquatic air-breathing fish Trichogaster microlepis in response to salinity variation. Comp Biochem Physiol A 155: 309-318.

IVERSEN M, FINSTAD B, MCKINLEY RS AND ELIASSEN RA. 2003. The efficacy of metomidate, clove oil, Aqui-S and Benzoak as anaesthetics in Atlantic salmon (Salmo salar L.) smolts, and their potential stress-reducing capacity. Aquaculture 221: 549-566.

LOWRY OH, ROSEBROUGH NJ, FARR AL AND RANDALL RJ. 1951. Folin Phenol Reagent. J Biol Chem 193: 265-275. 
LUSHCHAK VI AND BAGNYUKOVA TV. 2006. Effects of different environmental oxygen levels on free radical processes in fish. Comp Biochem Physiol B 144: 283-289.

LUSHCHAK VI, BAGNYUKOVA TV, LUSHCHAK OV, STOREY JM AND STOREY KB. 2005. Hypoxia and recovery perturb free radical processes and antioxidant potential in common carp (Cyprinus carpio) tissues. Int $\mathrm{J}$ Biochem Cell Biol 37: 1319-1330.

LUSHCHAK VI, LUSHCHAK LP, MOTA AA AND HERMES-LIMAM. 2001. Oxidative stress and antioxidant defenses in goldfish Carassius auratus during anoxia and reoxygenation. Am J Physiol Regul Integr Comp Physiol 280: 100-107.

MCDONALD DG, CAVDEK V AND ELLIS R. 1991. Gill design in freshwater fishes: interrelationships amongst gas exchange, ion regulation and acid-base regulation. Physiol Zool 64: 103-123.

MILSOM WK, SUNDIN L, REID S, KALININ A AND RANTIN FT. 1999. Chemoreceptor control of cardiovascular reflexes. In: Val AL and Almeida-Val VMF (Eds), Biology of Tropical Fishes, Manaus: INPA, Manaus, Brazil, p. 363-374.

MOYSON S, LIEW HJ, DIRICX M, SINHA AK, BLUST R AND DE BOECK G. 2015. The combined effect of hypoxia and nutritional status on metabolic and ionoregulatory responses of common carp (Cyprinus carpio). Comp Biochem Physiol A 179: 133-143.

NIKINMAA M. 2002. Oxygen-dependent cellular functions - why fishes and their aquatic environment are a prime choice of study. Comp Biochem Physiol A 133: 1-16.

OLIVEIRA UO, ARAÚJO ASR, KLEIN-BELLÓ A, SILVA RSM AND KUCHARSKI LC. 2005. Effects of environmental anoxia and different periods of reoxygenation on oxidative balance in gills of the estuarine crab Chasmagnathus granulate. Comp Biochem Physiol B 140: 51-57.

PELSTER B, WOOD CM, JUNG E AND VAL AL. 2018. Air-breathing behavior, oxygen concentrations, and ROS defense in the swimbladders of two erythrinid fish, the facultative airbreathing jeju, and the non-air-breathing traira during normoxia, hypoxia and hyperoxia. J Comp Physiol B 188: 437-449.

PERRY SF AND McDONALD G. 1993. Gas exchang. In: Evans DH (Ed), The physiology of fishes, Boca Raton: CRC Press, Boca Raton, USA, p. 251-278.

PIERSON PM, LAMERS A, FLIK G AND MAYERGOSTAN N. 2004. The stress axis, stanniocalcin, and ion balance in rainbow trout. Gen Comp Endocr 137: 263-271.

PIO JFG, PEREIRA TS, CALOR AR AND COPATTI CE. 2018. Organisation of the benthic macroinvertebrate assemblage in tropical streams of different orders in NorthEastern Brazil. Ecología Austral 28: 113-122.

REID SGAND PERRYSF. 2003. Peripheral $\mathrm{O}_{2}$ chemoreceptors mediate humoral catecholamine secretion from fish chromaffin cells. Am J Physiol 284: 990-999.
RIFFEL AP ET AL. 2012. Redox profile in liver of Leporinus macrocephalus exposed to different dissolved oxygen levels. Fish Physiol Biochem 38: 797-805.

ROBERTSON LM, VAL AL, ALMEIDA-VAL VMF AND WOOD CM. 2015. Ionoregulatory aspects of the osmorespiratory compromise during acute environmental hypoxia in 12 tropical and temperate teleosts. Physiol Biochem Zool 88: 357-370.

ROSSO FL, BOLNER KCS AND BALDISSEROTTO B. 2006. Ion fluxes in silver catfish (Rhamdia quelen) juveniles exposed to different dissolved oxygen levels. Neotrop Ichthyol 4: 435-440.

SPEERS-ROESCH B, MANDIC M, GROOM DJE AND RICHARDS JG. 2013. Critical oxygen tensions as predictors of tolerance and tissue metabolic responses during hypoxia exposure in fishes. J Exp Mar Bio Ecol 449: 239-249.

SUNDIN L. 1999. Hypoxia and blood flow control in fish gills. In: Val AL and Almeida-Val VMF (Eds), Biology of tropical fishes, Manaus: INPA, Manus, Brazil, p. 353-362.

TEIXEIRA RR, SOUZA RC DE, SENA AC, BALDISSEROTTO B, HEINZMANN BM, COUTO, RD AND COPATTI CE. 2017. Essential oil of Aloysia triphylla in Nile tilapia: anaesthesia, stress parameters and sensory evaluation of fillets. Aquac Res 48: 3383-3392.

TRIPATHI RK, MOHINDRA V, SINGH A, KUMAR R, MISHRA RM AND JENA JK. 2013. Physiological responses to acute experimental hypoxia in the airbreathing Indian catfish, Clarias batrachus (Linnaeus, 1758). J Bioscience 38: 373-383.

VERDOUW H, VANECHTELD CJA AND DECKKERS EMJ. 1978. Ammonia determinations based on indophenol formation with sodium salicylate. Water Res 12: 399-402.

WELKER AF, MOREIRA DC, CAMPOS EG AND HERMES-LIMA M. 2013. Role of redox metabolism for adaptation of aquatic animals to drastic changes in oxygen availability. Comp Biochem Physiol A 165: 384-404.

WILHELM FILHO DW. 1996. Fish antioxidant defenses - a comparative approach. Brazilian J Med Biol Res 29: 17351742 .

WILHELM FILHO DW, TORRES MA, ZANIBONI-FILHO E AND PEDROSA RCZ. 2005. Effect of different oxygen tensions on weight gain, feed conversion, and antioxidant status in piapara, Leporinus elongatus (Valenciennes, 1847). Aquaculture 244: 349-357.

WU RSS. 2002. Hypoxia: from molecular responses to ecosystem responses. Mar Pollut Bull 45: 35-45.

XU J, LIU Y, CUI S AND MIAO X. 2006. Behavioral responses of tilapia (Oreochromis niloticus) to acute fluctuations in dissolved oxygen levels as monitored by computer vision. Aquacult Eng 35: 207-217.

ZALL DM, FISHER MD AND GARNER QM. 1956. Photometric determination of chlorides in water. Anal Chem 28: 1665-1678. 